\title{
Immunological Studies in Multiple Sclerosis: Incidence of Circulating Antibodies to Dietary Proteins and Auto-antigens
}

\author{
RALPH WRIGHT,* M.D., M.R.C.P.; J. A. MORTON, $\dagger$ PH.D. ; K. B. TAYLOR,* $\ddagger$ D.M., M.R.C.P.
}

Brit. med. F., 1965, 1, 491-492

The possibility that multiple sclerosis may result from an abnormal immunological response has recently received some attention (Miller and Schapira, 1959 ; Smith et al., 1961 ; Lumsden, 1961). The antigens involved might be exogenous or auto-antigens or both.

Successful induction of autoimmune encephalomyelitis in various species of animals has been cited in support of the autoallergic pathogenesis of multiple sclerosis, although the experimental lesions are not very similar to those seen in multiple sclerosis.

If a disturbance of immune responsiveness is involved this may be expressed by the formation of auto-antibodies against some component of the central nervous system. Published findings of the incidence of antibodies to central nervous tissue have been conflicting (Sachs and Steiner, 1934 ; Kolb, 1950 ; Lumsden et al., 1950 ; Raskin, 1955 ; Steffen et al., 1955; Delank, 1957 ; Broman et al., 1960 ; Macleod et al., 1962 ; Caspary et al., 1964), and this question has not been further examined in the present study. Another possibility is that if multiple sclerosis were an autoimmune disease, then, consonant with the postulate of Hijmans et al. (1961), one might expect to find a spectrum of organ-specific auto-antibodies as has been described in autoimmune thyroid disease and pernicious anaemia, or an abnormal incidence of non-organ-specific autoantibodies as in systemic lupus erythematosus.

The sera of patients with multiple sclerosis have therefore been examined for antibodies to some exogenous antigensnamely, dietary proteins-and for antibodies to thyroid and gastric components and antinuclear and rheumatoid factors.

\section{Materials and Methods}

Sera were collected from 51 patients with a definite clinical diagnosis of multiple sclerosis. The group included both inpatients and out-patients in various stages of the disease; none of them was receiving treatment with corticosteroids. Control sera, matched for age and sex, were obtained from laboratory staff and from healthy visitors to general medical in-patients and stored at $-20^{\circ} \mathrm{C}$. in small aliquots until used for immunological testing.

\section{Serological Tests}

1. Antinuclear Factor.-The fluorescent antibody test using calf thymus nuclei was performed according to the method of Widelock et al. (1961).

2. Autoimmune Complement-fixation Test.-The supernatant of a saline homogenate of fresh rat liver was used as antigen and antibodies were detected by complement fixation as described by Gajdusek (1958).

3. Hyland Latex. Test for Rheumatoid Factor.-This test was carried out on glass plates, a $1 / 20$ dilution of serum being

\footnotetext{
* Nuffield Department of Clinical Med ine, Radcliffe Infirmary, Oxford. † Department of Pathology, Radcliffe ! Ifirmary, Oxford.

$¥$ Present adúress: Department of Medicine, Stanford University School of Medicine, California.
}

mixed with polystyrene-latex particles coated with gammaglobulin.

4. Thyroid Antibodies to (a) Thyroglobulin.-The tannedred-cell test was used for the detection of thyroglobulin antibodies using Wellcome preserved cells (Fulthorpe et al., 1961). (b) Acinar-cell Cytoplasm : Sera were tested for antibodies to the " microsomal" antigen of the thyroid acinar-cell cytoplasm by complement fixation, using fresh human thyroid as antigen (Roitt and Doniach, 1958) and by the immunofluorescent sandwich techinque using sections of unfixed human thyroid (Holborow et al., 1959).

5. Gastric-parietal-cell Antibodies.-Antibodies to gastricparietal cells were detected by the immunofluorescence technique using unfixed human stomach sections (Taylor et al., 1962).

6. Antibodies to Dietary Proteins.-The coated tanned-redcell test (Boyden, 1951), as modified by Gunther et al. (1960), was used for detecting antibodies to gluten fraction III (Frazer et al., 1959), purified bovine casein, $\alpha$-lactalbumin, and $\beta$-lactoglobulin, as described previously (Taylor et al., 1961). In addition, crystalline ovalbumin was used as antigen and tested in the same way.

A modification of the micro-Ouchterlony technique (Wadsworth, 1957) was also used in the case of the milk proteins.

Control sera and the sera from patients with multiple sclerosis were tested simultaneously. In the case of complement-fixation, latex, and tanned-red-cell tests all the sera were tested to one or more antigens in one batch. For the immunofluorescence tests the sera were tested in small batches consisting of equal numbers of multiple sclerosis and control sera matched for age and sex. Known positive and negative sera were used as additional controls in each instance. Fluorescein-conjugated rabbit antihuman gamma-globulin (Sylvana) was used in the Coons sandwich technique, fluorescence being detected by darkground ultra-violet microscopy using an Osram Hb 200 lamp.

\section{Results}

The incidence of gastric, thyroid, and non-organ-specific antibodies and of rheumatoid factor are set out in Table I.

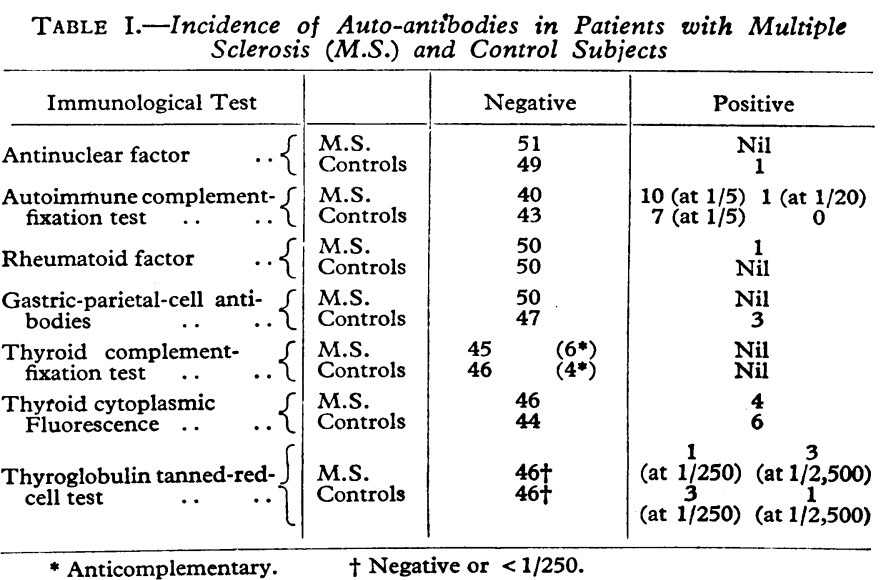


There is no significant difference between the multiple sclerosis and control sera with any of the tests used.

With the tanned-red-cell test for antibodies to dietary proteins, differences between multiple sclerosis and control sera were obtained for two of the purified milk proteins, $\alpha$-lactalbumin and $\beta$-lactoglobulin, which were highly significant. In the case of gluten fraction III, casein, and ovalbumin no differences were found (Table II).

TABLe II.-Incidence of Antibodies to Dietary Proteins in Patients with Multiple Sclerosis and Control Subjects

\begin{tabular}{|c|c|c|c|c|c|c|c|}
\hline & \multicolumn{6}{|c|}{ Serological Reaction } & \multirow{2}{*}{$\begin{array}{c}\text { Statistical Significance } \\
\text { of Difference (Combin- } \\
\text { ing Values for Titres of } \\
1 / 200 \text { and Above) }\end{array}$} \\
\hline & Neg. & $1 / 20$ & $1 / 200$ & $1 / 2,000$ & $1 / 20,000$ & Total & \\
\hline \multicolumn{8}{|c|}{ Gluten Fraction III } \\
\hline $\begin{array}{l}\text { M.S. } \\
\text { Controis }\end{array}$ & $\begin{array}{l}22 \\
53\end{array}$ & $\begin{array}{l}16 \\
28\end{array}$ & $\begin{array}{l}13 \\
15\end{array}$ & $\overline{2}$ & $=$ & $\begin{array}{l}51 \\
98\end{array}$ & $\begin{array}{c}\chi^{2}=2 \cdot 0 . \mathrm{n}=2 . \mathrm{P}>0.05 \\
\text { Not significant }\end{array}$ \\
\hline \multicolumn{8}{|c|}{ Casein } \\
\hline $\begin{array}{l}\text { M.S. } \\
\text { Controls }\end{array}$ & $\begin{array}{r}2 \\
10\end{array}$ & $\begin{array}{l}38 \\
71\end{array}$ & $\begin{array}{l}11 \\
15\end{array}$ & $\overline{2}$ & $=$ & $\begin{array}{l}51 \\
98\end{array}$ & $\begin{array}{c}x^{2}=2 \cdot 0 . \mathrm{n}=2 . \mathrm{P}>0.05 \\
\text { Not significant }\end{array}$ \\
\hline \multicolumn{8}{|c|}{ a-lactalbumin } \\
\hline $\begin{array}{l}\text { M.s. } \\
\text { Controis }\end{array}$ & $\begin{array}{l}12 \\
40\end{array}$ & $\begin{array}{l}23 \\
50\end{array}$ & $\begin{array}{r}13 \\
6\end{array}$ & $\begin{array}{l}3 \\
4\end{array}$ & $=$ & $\begin{array}{r}51 \\
100\end{array}$ & $\begin{array}{c}\chi^{2}=11 \cdot 8 . \mathrm{n}=2 . \mathrm{P}<0.01 \\
\text { Highly significant }\end{array}$ \\
\hline \multicolumn{8}{|c|}{$\beta$-lactoglobulin } \\
\hline M.S. .. & 2 & 27 & 16 & 5 & 1 & 51 & $\chi^{2}=13 \cdot 8, \quad \mathrm{n}=2$ \\
\hline Controls & 24 & 55 & 19 & 2 & - & 100 & Highly significant \\
\hline \multicolumn{8}{|c|}{ Ovalbumin } \\
\hline M.S. .. & 29 & 10 & 9 & 3 & - & 51 & $\begin{array}{l}\chi^{2}=1.08 . \\
P>0.05\end{array}$ \\
\hline Controls & 24 & 10 & 12 & 2 & 2 & 50 & Not significant \\
\hline
\end{tabular}

Tests for dietary proteins using the micro-Ouchterlony technique were uniformly negative.

\section{Discussion}

In the present study significant differences were found between patients with multiple sclerosis and control subjects in the incidence of antibodies to two of the purified proteins of cow's milk, $\alpha$-lactalbumin and $\beta$-lactoglobulin. It is noteworthy that the frequency of high-titre reactions was less in patients with multiple sclerosis than we have found previously in some gastro-intestinal diseases, especially idiopathic steatorrhoea (Taylor et al., 1961). In a more extensive study of these dietary proteins we have discussed possible explanations for these hightitre reactions. One explanation is that they may represent increased absorption of whole protein from the gastro-intestinal tract (Taylor et al., 1964).

Our study shows that there is no abnormal incidence of gastric and thyroid antibodies or of antinuclear and non-organspecific complement-fixing antibodies or of rheumatoid factor in multiple sclerosis. There is therefore no suggestion in multiple sclerosis of a pattern of disturbance of immunological responsiveness such as that found notably in Sjögren's disease, in autoimmune thyroiditis, in pernicious anaemia, and in systemic lupus erythematosus.

The rarity of these antibodies in patients with multiple sclerosis may be of some value in differential diagnosis. Since gastric-parietal-cell antibodies are found in almost all cases of pernicious anaemia and are negative in cases of multiple sclerosis, the test may be of value in distinguishing the latter from subacute combined degeneration of the cord. Similarly, the finding of a positive antinuclear factor in an obscure neuropathy would favour a generalized disease, such as systemic lupus erythematosus, rather than multiple sclerosis.
From the present study no conclusion on the pathogenesis of multiple sclerosis can be drawn.

Shatin (1964), on the basis of epidemiological evidence, has suggested that multiple sclerosis may be the result of gluten intolerance and that the primary lesion is in the small intestine. In the present study the incidence of antibodies to gluten in patients with multiple sclerosis did not differ from that in control subjects. The positive finding of an abnormally high incidence of serum antibodies to milk proteins may be due to involvement of some immunological phenomenon or to some nutritional factor, the immunological changes merely reflecting high consumption of milk products ; this remains to be resolved.

\section{Summary}

Specimens of serum from 51 patients with multiple sclerosis have been tested for antinuclear factor, rheumatoid factor, thyroid and gastric antibodies, and non-organ-specific complement fixation. When compared with a healthy control group matched for age and sex there was no significant increase in the incidence of these antibodies. In addition, the sera have been tested for antibodies to several dietary proteins. Sera from patients with multiple sclerosis showed a significantly greater incidence of antibodies to two of the purified proteins of cows' milk, $\alpha$-lactalbumin and $\beta$-lactoglobulin, than sera from the controls, but high-titre reactions were infrequent in both groups. The antibody titres to casein, ovalbumin, and gluten fraction III closely resembled the levels in a control group.

The signifieance of the findings in relation to current theories of an immunological disturbance as the underlying cause in multiple sclerosis is discussed.

We wish to thank Professor L. J. Witts for facilities, and Dr. Honor V. Smith for allowing us to take specimens of serum from patients under her care. Expenses were met in part by grants from the Medical Research Council and U.S. Public Health Service Grant No. AM 06971-03.

\section{REFERENCES}

Boyden, S. V. (1951). F. exp. Med., 93, 107.

Broman, T., Lidvall, H., Lind, A., and Meyer, P. (1960). Acta psychiat. scand., 35, 403. Caspary, E. A., Field, E. J., and Ball, E. J. (1964). F. Neurol. Neurosurg.

Delank, H. W. (1957). Arch. Psychiat. Nerverkr., 195, 383.

Frazer, A. C., Fletcher, R. F., Ross, C. A. C., Shaw, B., Sammons, H. G., and Schneider, R. (1959). Lancet, 2, 252.

Fulthorpe, A. J., Roitt, I. M., Doniach, D., and Couchman, K. (1961). F. clin. Path., 14, 654 .

Gajdusek, D. C. (1958). Arch. intern. Med., 101, 9. Gunther, M., Cheek, E., Matthews, R. H., and Coombs, R. R. A.

Hijmans, W., Doniach, D., Roitt, I. M., and Holborow, E. J. (1961). Brit. med. F., 2, 909.

Holborow, E. J., Brown, P. C., Roitt, I. M., and Doniach, D. (1959). Brit. F. exp. Path., 40, 583 .

Kolb, L. C. (1950). Medicine (Baltimore), 29, 99.

Lumsen, C. (1961) Proc, roy. Soc. Med., 54, 11.

Kabat, E. A., Wolf, A., and Bezer, A. E. (1950). F. exp. Med., 92 , 253.

Macleod, I., Ridley, A. R., Smith, C., and Field, E. J. (1962). Brit. med. 7., 1,1525 .

Miller, H., and Schapira, K. (1959). Brit. med. F., 1, 737, 811.

Raskin, N. (1955). Arch. Neurol. Psychiat. (Chic.), 73, 645

Roitt, I. M., and Doniach, D. (1958). Lancet, 2, 1027.

Sachs, H., and Steiner, G. (1934). Klin. Wschr., 13, 1714.

Shatin, R. (1964). Neurology (Minneap.), 14, 338

Smith, H. V., Hughes, I. E., and Hunter, G. (1961). F. Neurol. Neurosurg. Psychiat., 24, 101.

Steffen, C., Tschabitscher, H., Wanko, T., and Schinko, H. (1955). Wien. klin. W schr., 67, 763.

Taylor, K. B., Roitt., I. M., Doniach, D., Couchman, K. G., and Shapland, C. (1962). Brit. med. F., 2, 1347. med. F., 2, 1727 .

med. 7., 2, 1727. and Wright, R. (1964). Gastroenterology, 46, 99. Wadsworth, C. (1957). Int. Arch. Allergy, 10, 355.

Widelock, D., Gilbert, G., Siegel, M., and Lee, S. (1961). Amer. F. publ. Hith, 51, 829 . 